iRASD Jounral of Economics
Volume 1, Number 1, 2019, Pages $42-58$
JRASD
Journal Homepage:
https://journals.internationalrasd.org/index.php/joe

\title{
Impact of Budget Deficit on Inflation: A Case Study of Pakistan
}

Muhammad Hamza ${ }^{1}$, Muhammad Azhar Bhatti ${ }^{2}$, Kokab Kiran ${ }^{3}$

${ }^{1}$ MS Scholar, Forman Christian College, Lahore, Pakistan, Email: 213526917@formanite.Fccollege.edu.pk ${ }^{2}$ PhD Scholar, Department of Economics, The Islamia University of Bahawalpur Email: azhar.bhatti219@gmai.com ${ }^{3}$ Mphil Scholar, Department of Economics, The Islamia University of Bahawalpur Email: kokabkiran6@gmail.com

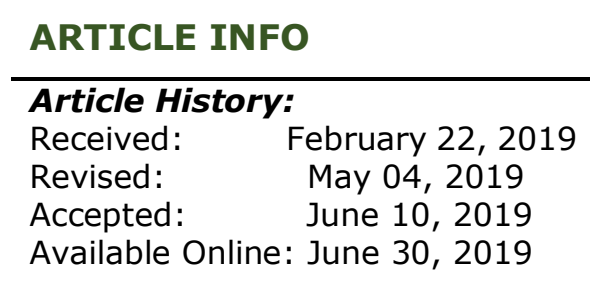

\footnotetext{
Keywords:

Fiscal deficit

Inflation

Money supply
}

\section{JEL Classification Codes: E31, E51, O23}

\section{Funding:}

This research received no specific grant from any funding agency in the public, commercial, or not-forprofit sectors.

\section{ABSTRACT}

The research is concerned with examining the influence of budgetary shortfall on inflation a case study of Pakistan's economy. As inflation is one of the most prominent macro-economic indicators which tells us about how the prices in the country are reacting and subsequently how other factors are being affected. So in the present study, we have inspected the influence of budgetary shortfall on inflation. Pakistan is in the growing phase where inflation and budget deficit are two major issues so for that reason we included the ramification of a budget deficit. The Principal variable is money hike and independent variables are supply of money, GDP improvement, joblessness, the official rate of exchange, and fiscal deficit. The data is from 1985 to 2017. For checking unit root study applied the ADF test and for regression, we applied the Auto Regressive Distributed Lag Model (ARDL) method. The data was fetched from the "World development indicator" and "Pakistan Economic Survey". The results conclude that budgetary shortfall, GDP growth, and supply of money have a significant positive impact while unemployment and the official rate of exchange have a negative impact. The study recommends that leaders should focus on generating new revenue sources rather than foreign financing.

\section{OPEN ACCESS}

(C) 2019 The Authors, Published by iRASD. This is an Open Access Article under the Creative Common Attribution Non-Commercial 4.0

Corresponding Author's Email: 213526917@formanite.Fccollege.edu.pk

Citation: Hamza, M., Bhatti, M. A., \& Kiran, K. (2019). Impact of Budget Deficit on Inflation: A Case Study of Pakistan. IRASD Journal of Economics, 1(1), 42-58.

https://doi.org/10.52131/joe.2019.0101.0004

\section{Introduction \\ 1.1 Inflation}

It is defined as a consistent increase in the worth of general commodities and services in the economy for a specific time interval. As the value of goods and services goes up, each currency unit can now buy lesser goods and services or we can say that as the price level increases consumer purchasing power decreases. The quantification of CPI is the expansion rate, the annualized rate change in a general value list, for the most part, the customer value list overtime. The opposite of inflation is deflation. It influences economies in both ways. We will first study the negative affect which is an increase in the economic cost of holding cash, fluctuations in prices cause' loss of investors' confidence which leads to a decrease in investment. On the other side, the positive effect is a reduction in the joblessness rate because of declared compensation firmness allowing the national bank all the more breathing 
space in finishing the financial course of action, engaging credit and venture as opposed to money amassing and keeping up a key good ways from the inefficient angles related with deflation. It is a general belief that the excessive expansion of the supply of money causes a high rate of CPI. The following are some reasons which cause inflation:

1) Huge fiscal deficits

2) Monetizing deficits

3) Mega foundation ventures by city, commonplace, and governments

4) Huge defense spending's

5) Political distress

6) Strong inflationary desires for monetary operators

7) Inflationary impacts of changes in the rate of exchange through increment in costs of external sources.

The duty of maintaining the rates of inflation lower \& constant is allocated to financial institutions. Usually, these institutions are the reserve banks as in Pakistan it is the state bank of Pakistan. The role of a state bank is to keep a check on financial policies through the adjustments of lending rates through open market exercises and the setting of banking hold prerequisites.

\subsubsection{Budget Deficit}

The budget deficit is a condition in which expenses increase the total income. The budget deficit generally relates to government expenditures and not business or individual spending. Any government or business which is in debt can only be recovered by external borrowing from different sources. The budget deficit is the simplest tool which analyst use to check the financial health of the country. The budget deficit is a major problem faced by many developing nations. Deficit exerts negative pressure on the government. A nation wishing to address its spending lack may need to diminish certain utilization, increase salary creating practices, or use a mix of two. Budget can be of two types it can be surplus or it can be a deficit. We will first explain the budget deficit. It is a condition where our current expense is greater than our current revenues. There is a shortage of resources and this gap is then bridged by external/internal borrowing. A budget surplus is a condition when our present income expands current costs and this condition brings about overabundance subsidizes that can be dispensed as desired. The condition where the Incomings equals the outgoing, the budget is said to be balanced. Budget deficit possesses different threats one of which is CPI, which is the persistent increase in the prices. If we take the example of the US (United States), a spending deficiency can make central banks release more money into the economy, which deals with development. Over the long haul, a downturn will happen which addresses a decline in money related activities that continue for a half year in any event. Countries can overcome this issue in various ways. Progressing money related advancement through financial methodologies, for instance, diminishing government spending and growing charges, for example, one procedure is to decrease rules and lower corporate appraisals to improve business conviction and augmentation treasury inflows from charges. A nation can print additional cash to cover portions on commitments giving assurances, for instance, treasury bills and protections. While this gives an instrument to make portions, it passes on the risk of devaluing the nation's cash which can provoke hyperinflation. Spending deficiency can likewise happen because of reaction to certain unexpected occasions and strategies for instance expanded resistance spending after the September 11 dread assaults in the US added to spending shortfall, while the underlying war in Afghanistan cost an expected 30 billion (USD). Spending shortfall reflected as a level of GDP may diminish amid financial flourishing, as expanded duty income, lower joblessness rates, and expanded monetary 
development lessen the requirement for government-supported projects, for example, joblessness.

\subsubsection{Theories behind This Link}

As budget deficit increases in a nation, it creates problems in the economy to finance this deficit there are various ways and theories which we are going to explain. One way to do this is to print new currency notes to cover this gap. From theory, we know that as the supply of money will increase in the economy it will lead towards inflation. This means that the supply of money and inflation is positively related. Inflation increases at a similar rate as of money supply. While other things remaining the same, the level of prices is consistent with the $M_{2}$. Multiplying the money supply will multiply the value of commodities and services in the economy. The money supply is exogenous which is monitored by a central bank. It can make it larger or smaller. The monetary theory of inflation is a long-run theory. Quicker or slower development in a specific year may not cause quicker or slower inflation. Another macroeconomic theory that describes the link between fiscal shortfall and inflation states that fiscal deficit can be funded through borrowing it may be external or internal. Internal borrowing is done from private financial institutes present in the country. These private institutes also provide funds to the private sector for business purposes but the issue is when the government intervenes in this sector the demand for loanable funds increases but the supply is limited which will cause the inflation to rise. Because of a rise in the interest rate the cost of producing commodities and services increases. The producer will increase the price of goods which is also called inflation. So according to this theory, we can also see a positive relationship between budgetary shortfall and CPI. Due to this the private sector will drift out from the economy. The classical way of thinking considers inflation as a result of financial extension and the amount hypothesis of cash as a clarification for this. In any case, the best possible transmission component in clarifying the inter-link is deficient. The Keynesians accentuate request to be central point dependable in explaining changes in the worth level. Monetarists grasp cash flexibly as a sole explanation of CPI. Anyway, they didn't bolster the harmonious arrangement ideas which were introduced by classical financial specialists. Friedman is the greatest defender of this way of thinking and respected inflation wherever is a money related marvel. Monetarist way of thinking is of the view that when there is a persevering increment in financial shortfalls then governments select the least demanding decision of financing, an adaptation of deficiency, which will, in the end, raise value level. Macroeconomics is that administrations running constant deficiencies have sooner or later to back those deficiencies with cash creation, accordingly delivering inflation. Experimental work had little achievement in finding the solid and critical association between financial shortfalls and inflation. Protopapadakis and Siegel (1987) found no proof between administration obligation development and inflation. Hondroyiannis and Papapetrou (1997) don't locate any immediate effect of the spending shortage on inflation in Greece. Darrat (2000) recommends that other than controlling for money improvement, higher spending deficiencies have furthermore played an important and direct activity in the Greece inflationary procedure. Dhakal, Kandil, Sharma, and Trescott (1994) present proof strong of the impacts of spending shortages on inflation. Aghevli and Khan (1978) found a direct connection between CPI and spending shortfall.

\subsection{Problem Statement}

Various studies are done on the impact of spending deficiency on inflation. Many researchers have used various techniques to cover the broad area of a budget deficit. This study is used to cover the basic problem of why still Pakistan could not cover up the gap of deficit although many steps were taken to bridge this gap. We will also investigate the problem that is budget deficit inflationary or not. Pakistan economic survey report (2016-17) says that 
the fiscal deficit of Pakistan in the year 2017 is nearly 5.70 percent of GDP Indicating the problem of fiscal deficit.

\subsection{Research Question}

The fundamental question which the study tried to examine is, What is the impact of budget deficit on Inflation in Pakistan?

\subsection{Objectives of the Study}

To investigate the impact of a monetary shortage on inflation.

To investigate the effect of $\mathrm{M}_{2}$ on inflation.

To investigate the effect of total unemployment on inflation.

To investigate the effect of GDP growth on inflation.

To investigate the effect of the official exchange rate on inflation.

\subsection{Significance}

This study will help various audiences such as it will provide information to the policymakers who are related to making policies to lessen the budget deficit and inflation. It will also help students and other researchers by giving a new dimension in studying this problem of budget deficit specifically in Pakistan. This study also includes those variables which have not been used commonly in various studies.

\subsection{Scope of the Study}

This study has taken inflation as a principal variable while the independent variables taken were fiscal deficit, GDP growth, money supply, official exchange rate, and total unemployment. Adding these variables increases the scope of study and it will now cover various aspects that can affect our dependent variable. The time period of this study is wide then the previous studies giving more accurate answers which will help incorrect policy recommendations. The timeframe of the study is from 1985 to 2017 . The study is based on Pakistan.

\section{Literature Review}

Egwaikhide, Chete, and Falokun (1994) researched the numeric impacts of the rate of exchange devaluation on CPI, government income/uses, and cash flexibly in Nigeria. In the wake of testing for the internal consistency of the complete model, it was applied to evaluate the effect of conversion scale deterioration on cash gracefully, incomes/uses, and expansion. Proof from the model outcomes, in which we accepted a floating exchange rate, in the long term, will lead to devaluation of the naira and demonstrates that conversion standard deterioration can be inflationary. This works utilizing its immediate effect on inflation and through budgetary and money related impacts. By and large, the deterioration of the naira (by about $76 \%$ ) appears to raise the development of all-out consumption more than absolute income.

Chaudhary, Ahmad, and Siddiqui (1995)carried out research to study $M_{2}$, spending shortage, and CPI in Pakistan. This paper has used the 2sls method. The examination recommended that local financing of spending shortfall is inflationary in the long haul it additionally proposed that to discharge inflation pressure government should reduce the budget deficit. These results support the constructive relationship between inflation and fiscal 
shortfall when CPI was severe (the 1970s. It concludes that the government should focus on creating new business activities to generate revenue and release some pressure on it.

Akcay, Alper, and Ozmucur (1996) studied the notion stated money supply, fiscal deficit, and inflation: proof from low and high commonness information for Turkey. The objectives of the study were to obtain the path through which the fiscal deficit of Turkey was working after World War 2 when the financing of bonds was considered as the source of deficit financing. VAR and VEC were used. By using the VAR model they found a weak relation between inflation and other variables. The elevated inactivity of inflation could be explained as a buildup of inflationary presumption.

ur Rehman, Ahmed, and Ali (2008) analyzed the influence of fiscal shortfall on CPI in Pakistan. It was conducted to check the relationship of the budgetary shortfall and inflation in Pakistan. OLS was used for estimation. The outcome showed that fiscal shortfall, a supply of money, and import costs have a constructive outcome on inflation but the only significant variable is the money supply. As it means if we contract budget deficit through deficit financing such as producing new notes which will lead to a rise in prices.

(Soomro \& Memon)carried out research to check the interface between financial shortfall and inflation in Pakistan. Objectives were to observationally consider the effect of the government spending deficiency and inflation. OLS method was used to analyze the association between budget deficit and inflation. To check the long term and short term association cointegration and error correction mechanism were used. The study presumes that downfall in imports and spending shortage can lessen inflation prominently.

Lozano-Espitia (2008) explored the notion of money growth, fiscal deficit, and inflation: evidence from the Colombian case. VEC model was adopted for this purpose. It showed a long-run association between CPI and supply of money as compared to other states with a different or parallel method. The vector error correlation method provides strong proof which says a $1 \%$ increment in the spending deficiency will eventually go to make an increment of nearly $.46 \%$ points in $\mathrm{m} 1$ growth rate. Long run association between fiscal shortfall, growth of money and CPI may change which depends upon the degree of autonomy of the state bank as it was also covered in various other studies.

Serfraz and Anwar (2009) explored the connection between monetary irregular characteristics \& CPI in Pakistan. The goal of the paper was to break down the impact of ascending in cash flexibly markers on the pattern of expansion in Pakistan. Johnson cointegrated test and vector autoregressive model were utilized to get précised results. Utilizing different tests it was discovered that Inflation is influenced by inward/outside acquiring and $M_{2}$. They found out that there exists a long term association between spending deficiency and inflation. They proposed that Pakistan must give sharp consideration on acquiring strategy with the goal that expansion ought to be limited.

Mukhtar and Zakaria (2010) examined the notion that said that elevated fiscal deficit gives rise to inflation in Pakistan. There are two goals of this paper first to analyze the connection between the supply of money, inflation, and fiscal deficit in Pakistan and the second objective of the paper was to figure out the direction of causality between them. To check the presence and number of cointegrated vectors they used a cointegration test. For granger causality, they used the causality test. Paper concludes no long term connection between fiscal shortfall and CPI in Pakistan and secondly did not have any proof which proposes that adjustments in spending shortfall prompt change in money related development in Pakistan. 
Habibullah, Cheah, and Baharom (2011) researched the connection between spending shortage and inflation in 13 progressing nations. Error correction model and co-integration were utilized for long term investigation and the short-run granger causality test was utilized. The outcome shows that all the factors are of 1st order. This examination found that spending deficiency is inflationary and the existence of long-run connection in between them.

Tiwari and Tiwari (2011) investigated the relationship in-between fiscal shortfall and inflation in India. The purpose of the paper was to concentrate every one of those elements that contribute towards increasing fiscal shortfall in India. The examination finds that CPI isn't at all reasons for the financial shortfall. In any case, government consumption and cash flexibly are seen as significant determinants of mounting financial shortfall. Relapse results additionally disclose to us that $M_{2}$ has a negative connection while government use has a positive connection with monetary deficiency.

Samimi and Jamshidbaygi (2011) examined the connection between spending shortfall and inflation which is usually questionable from the theoretical perspective. This paper outlined the association between spending lack and inflation in Iran. To do all things considered, they used the simultaneous equation model, including four fundamental conditions for spending insufficiency, money related base, money gracefully, and inflation. Results show a positive and basic impact of the spending lack on financial elements and as an outcome of inflation.

Fatima, Ahmed, and Rehman (2011)investigated the connection between fiscal shortfall and economic expansion she further questioned the influence of fiscal shortfall on speculation and GDP expansion. They have made two equations one will check the direct effect and the other will check the indirect effect so to estimate these equations they used 2sls method. Results showed that fiscal deficit affects growth negatively. They suggested that the government should decrease the interest rate to attract investors.

Kakar (2011) investigated the influence of monetary factors on a financial turn of events in Pakistan. Various econometric techniques were used to check this relationship like the co-integration test, error correction, and granger casualty test. The study found that government policy affects the lucrative development in Pakistan.

Fatima, Ahmed, and Rehman (2012) explored the effect of a fiscal shortfall on lucrative growth. The reason for the investigation was to find various causes of a fiscal shortfall. The study concluded the pessimist influence of fiscal shortfall on lucrative growth was due to a lack of resources. Creators recommended that the legislature should utilize those resources which are not in use to overcome the problem of the budget deficit.

Aamir (2015) explored the relationship and effect of cash development and spending shortage on inflation in Pakistan. ANOVA table was utilized to measure the variations. The results showed the presence of a positive connection and the influence of cash development on inflation. Whenever inflation increases money growth decreases. The study also said that state banks and other financial institutes must deal with a budget deficit.

Tiwari, Bolat, and Koçbulut (2015) investigated the association between spending deficiency and CPI. Different econometric strategies were utilized to test the relationship, for example, Granger causality approach, sim's causality approach, VAR causality approach, and Yamamoto approach. This examination found that there was no immediate connection between spending shortage and inflation. 
Ishaq and Mohsin (2015) researched the thought deficiency and expansion: Are money related and budgetary establishments qualified to consider or not? GMM strategy was utilized in this examination. The outcomes show that spending shortfall is inflationary.

Muhammad, Zafar, Noman, and Arfeen (2016) researched the inter-link between fiscal shortfall and CPI in Pakistan. ARDL approach used to test this relation. This study found that in the case of Pakistan as $M_{2}$ increases exchange rate decreases which causes a rise in inflation. Paper also suggested that financial borrowing to decrease budget deficit should be considered as the last option before that the public sector should try to expand its growth.

Iqbal, ud Din, and Ghani (2017) explored the connection between monetary shortfall and financial development in Pakistan to check whether there is the presence of any boundary monetary shortage that can fill as a base for strategy producers intending to improve development by monetary extension for co co-integration; they have utilized the ARDL approach. To check the limit level of monetary shortfall they have utilized the star model. The investigation found that there exists a negative inter-link between monetary shortfall and financial improvement. This investigation recommended that the macroeconomic approach should keep spending shortage underneath the limit level to maintain a strategic distance from its outcomes on development and it additionally said that monetary deficiency beneath the edge level is attractive because it might improve financial development.

\section{Methodology}

This chapter permits us to understand the network of the inter-link between our variables. Variable included in the study are inflation measured by GDP deflator, money supply, fiscal deficit, GDP growth, unemployment total, and official exchange rate.

$\mathrm{INF}=\beta_{0}+\beta_{1} \mathrm{FD}+\beta_{2} \mathrm{MS}+\beta_{3} \mathrm{UNEMP}+\beta_{4} \mathrm{GDP}+\beta_{5} \mathrm{OED}+\mu$

\section{Table 1}

\section{Description of variables}

\begin{tabular}{ll}
\hline Variables & \multicolumn{1}{c}{ Description } \\
P* & Inflation \\
FD & Fiscal deficit \\
MS & Money supply \\
OED & Official exchange rate \\
UNEMP & Unemployment \\
GDPG & Gross domestic product growth \\
\hline
\end{tabular}

\subsection{Theoretical Model and Selection of Variables}

In this section, we will explain techniques that are used for estimations and testing the hypothesis for the paper. To see the influence of fiscal deficit and other factors on inflation the following model has been created.

$\mathrm{INF}=\beta_{0}+\beta_{1} \mathrm{FD}+\beta_{2} \mathrm{MS}+\beta_{3} \mathrm{UNEMP}+\beta_{4} \mathrm{GDP}+\beta_{5} \mathrm{OED}+\mu$ 
Table 2

Variable's definition and their anticipated signs

\begin{tabular}{|c|c|c|c|}
\hline Variables & Measurement & Source & Expected Sign \\
\hline $\begin{array}{l}\text { Inflation (GDP } \\
\text { deflator) }\end{array}$ & $\begin{array}{l}\text { Inflation, GDP deflator } \\
\quad(\text { annual \%) }\end{array}$ & $\begin{array}{l}\text { World Bank national accounts } \\
\text { data, and OECD National } \\
\text { Accounts data files. }\end{array}$ & Dependent variable. \\
\hline Money supply & $\begin{array}{l}\text { Broad money }(\% \text { of } \\
\text { GDP) }\end{array}$ & $\begin{array}{l}\text { International Monetary Fund, } \\
\text { International Financial } \\
\text { Statistics and data files, and } \\
\text { World Bank and OECD GDP } \\
\text { estimate. }\end{array}$ & Positive \\
\hline GDP growth & GDP growth (annual \%) & $\begin{array}{l}\text { World Bank national accounts } \\
\text { data, and OECD National } \\
\text { Accounts data files. }\end{array}$ & Positive/ Negative \\
\hline $\begin{array}{l}\text { Official } \\
\text { exchange } \\
\text { rate }\end{array}$ & $\begin{array}{l}\text { Official exchange rate } \\
\text { (LCU per US\$, } \\
\text { period average) }\end{array}$ & $\begin{array}{l}\text { International Monetary Fund, } \\
\text { International Financial } \\
\text { Statistics. }\end{array}$ & Negative \\
\hline $\begin{array}{l}\text { Unemploymen } \\
\text { t total }\end{array}$ & $\begin{array}{l}\text { Unemployment, total } \\
\text { (\% of the total labor } \\
\text { force) (national } \\
\text { estimate) }\end{array}$ & $\begin{array}{lr}\text { International } & \text { Labor } \\
\text { Organization, } & \text { ILOSTAT } \\
\text { database. Data retrieved in } \\
\text { April 2019. }\end{array}$ & Negative \\
\hline Fiscal deficit & & Pakistan economic surveys. & Positive \\
\hline
\end{tabular}

\subsection{Data Source}

This examination utilized the yearly information of data which ranges from 1985 2017 to check the idea of the connection between CPI and fiscal shortfalls and other different variables both in the long and short term. Numeric data is fetched from WDI (world development indicator) and various reports of the Economic Survey of Pakistan. The Inflation measured by GDP deflator (annual \%) is taken as the principal variable, whereas, the $M_{2}$, GDP growth (annual \%), Budget deficit, the official rate of exchange (LCU per US\$, period average) and Total unemployment (\% of the total labour force) (national estimate)are taken as the independent variables.

3.3 Mathematical Form of the Model

INF $=\beta_{0}+\beta_{1}$ FD $+\beta_{2}$ MS $+\beta_{3}$ UNEMP $+\beta_{4}$ GDP $+\beta_{5}$ OED $+\mu$

Table 3

Description of variables

\begin{tabular}{|l|l|l|}
\hline Variables & Description & Measurement \\
\hline GDPDEF & GDP deflator & (annual $\%$ ) \\
\hline BD & Budget deficit & \\
\hline OER & Off-exchange rate & LCU per US\$ \\
\hline M2 & Broad money & $\%$ of GDP \\
\hline UNEMP & Unemp Total & $\%$ of the total labour force \\
\hline GDPG & GDP growth & annual $\%$ \\
\hline
\end{tabular}




\subsubsection{Model Specification}

As indicated by the necessity of my examination I need to contemplate the effect of spending a shortage of inflation. The principal variable is inflation and the autonomous factors are fiscal deficit, M2, unemployment total, GDP development, and the official rate of exchange. The model utilized for the examination is the regression model. For this, I have utilized the Auto-Regressive Distributed Lag Model (ARDL). The data is fetched from World Development Indicators (WDI) and different reports of the Economic overview of Pakistan. An empirical examination is performed by utilizing econometric program E-View 9. Time series data of 32 years from 1985 to 2017 was used and the information utilized on this examination is restricted to those accessible and open inside authentic statistical limitation. The effect of inflation on spending shortfall is to be assessed as follows. The model is:

$\mathrm{INF}=\beta 0+\beta 1 \mathrm{FD}+\beta 2 \mathrm{MS}+\mathrm{B} 3 \mathrm{UNEMP}+\beta 4 \mathrm{GDP}+\beta 5 \mathrm{OED}+\mu$

The inter-link between the principal and independent variables are; Where the

$\beta_{0}=$ Coefficients of the variables

$\beta_{1}=$ Parameter of independent variable fiscal deficit

$\beta_{2}=$ Parameter of the independent variable money supply

$\beta_{3}=$ Parameter of independent variable official exchange rate

$\beta_{4}=$ Parameter of independent variable total unemployment

$\beta_{5}=$ Parameter of independent variable gross domestic product growth

In this equation inflation is the principal variable and fiscal shortfall, supply of money, official rate of exchange, GDP expansion, and total unemployment are the independent variables.

\subsection{The Data and Estimation Technique}

In this experimental investigation, we use yearly Time Series data from 1985-2017 and the source of data is World Development Indicators (WDI) and Pakistan Economic Surveys. The source for the variables used in the model is also the World Development Indicators (WDI) and Pakistan Economic Surveys. Generally, econometric time series information is non-stationary. It's critical to check the stationarity of information before applying the model that weather the unit root exists in data or not. An augmented dickeyfuller (ADF) test could be utilized for checking the stationarity of the information. Depending on stationary we will use the following econometric techniques. If all factors are fixed at level, at that point study will infer OLS Technique and if all of the factors are fixed at first contrast, at that point study will imply Johnson co-integration and if a variable is stationary in mixed order then we will use ARDL.

\subsection{Tests for Stationary}

\subsubsection{Augmented Dickey-Fuller Test}

It's the expanded form of Dickey-Fuller. In executing the Dickey-Fuller test it should be accepted that the error term $\mu$ t was uncorrelated. Yet, for the situation the assumption that is abused and $\mu$ is connected, Dickey and Fuller have built up a test, well studied as the Augmented Dickey-Fuller (ADF) test. It is augmented by adding the previous numbers of the dependent variable $\Delta \mathrm{Y}_{\mathrm{t}}$

$$
\mathrm{Y}_{\mathrm{t}}=\beta 1+\beta 2+\delta \mathrm{Y}_{\mathrm{t}-1}+\alpha_{\mathrm{i}} \sum \Delta \mathrm{Y}_{\mathrm{t}-1}+\mathrm{t}
$$


Presently $\mathrm{t}$ is pure white noise term and $\Delta Y_{t-i}=Y_{t-i}-Y_{t-2}$ as $\mathrm{i}=1$. It is sequentially uncorrelated and follows a similar conveyance as DF. Since the test is done over the remaining term as opposed to crude information, it is beyond the realm of imagination to expect to utilize usual t-distribution to give evaluative values. Hence this measurement has a particular dispersion just known as the Dickey-Fuller table.

The speculation is:

$\mathrm{H}_{\mathrm{o}}: \delta=0$ denotes unit root.

$\mathrm{H}_{1}: \delta \neq 0$ denotes no unit root.

Choice principle:

If $t^{*}>$ ADF evaluative value, $==>$ don't reject $H_{0}$ hypothesis, i.e., indicate existence of unit root.

If $\mathrm{t}^{*}<\mathrm{ADF}$ evaluative value, $==>$ do reject $\mathrm{H}_{\mathrm{o}}$ hypothesis, i.e., indicates unit root does not exists.

\subsubsection{Autoregressive Distributed Lag Model (ARDL)}

A General test to assess the cointegration among the factors is the Johansen cointegration test or Engle-Granger approach. These strategies have two principle issues. The initial one is that it requires the information to be incorporated into the same request. Furthermore, little information estimation gets troublesome by utilizing such methods. To defeat these issues Autoregressive Distributed Lag (ARDL) test was presented by Pesaran and Shin (1999). This test-principal variable is backslid upon its past worth including current and past estimations of other logical factors. As the model will be attempted through the ARDL bounds system that depends upon F statistics, the Bounds test will show that either the elements are co-incorporated or not.

$\mathrm{H}_{0}=$ There is no cointegration among the factors.

That is $\boldsymbol{\beta}_{0}=\boldsymbol{\beta}_{1}=\boldsymbol{\beta}_{2}=\boldsymbol{\beta}_{3}=\boldsymbol{\beta}_{4}=\boldsymbol{\beta}_{5}=\mathbf{0}$

$\mathrm{H}_{1}=$ There is cointegration among the factors.

That is $\beta_{0} \neq \beta_{1} \neq \beta_{2} \neq \beta_{3} \neq \beta_{4} \neq \beta_{5} \neq 0$

\subsubsection{Bound Test Approach of Cointegration}

It is used to inspect the drawn-out association between each arrangement of variable it doesn't require pretesting of the components associated with the model for unit roots not at all like different procedures, for example, Johansen co-combination approach. For the authenticity of the bound test approach, we utilized F Statistics measures for this we make an invalid and substantial theory. This examination embraces the ARDL - Bounds Test approach which depends on OLS estimation of a contingent of error correction model for cointegration investigation created by Pesaran et.al.(2001). This procedure is utilized here to check the co-integration. The coefficients of ARDL will show a long-run balance relationship while ECM coordinates short-run elements with long-run equilibrium. The method used in this investigation has a few focal points, for example, it can deal with a little example without any problem. This test can likewise apply regardless of whether factors have no equivalent request for coordination. Another significance of this method is that it can remember dummy factors for the model. This strategy permits us to incorporate various lags for every factor, while in VAR the request for the lag is the same for all the factors.

The speculation is:

$\mathrm{H}_{\mathrm{o}}$ : it implies no co-integration

$\mathrm{H}_{1}$ : it implies co-integration exist. 


\section{Results and Discussion}

The center target of this examination is to see how the fiscal deficit and other variables affect inflation in Pakistan. In this chapter, we will discuss the result obtained by the methodology; we applied the ADF unit root test and ARDL technique that has been discussed in chapter 4 . In this chapter, we present the result for 32 years of Pakistan.

\subsection{Descriptive Summary Statistic}

We present the summary statistic to explore the characteristic of variables used in the model. Table 4 in Pakistan is shown the descriptive statistic of all variables. The sample includes the Pakistan data and time series analysis time period from 1985 to 2017.

\section{Table 4}

\section{Descriptive Statistic of Variables}

\begin{tabular}{llllll}
\hline Variables & Observations & Mean & Maximum & Minimum & Standard dev \\
GDPDEF & 38 & 9.158 & 24.891 & 0.400 & 5.245 \\
BD & 38 & 5.149 & 10.829 & -1.033 & 2.912 \\
OER & 38 & 49.594 & 105.455 & 9.900 & 31.552 \\
M2 & 38 & 46.651 & 58.867 & 38.594 & 5.923 \\
UNEMP & 38 & 3.821 & 7.8300 & 0.397 & 2.224 \\
GDPG & 38 & 4.899 & 10.215 & 1.014 & 2.098 \\
\hline
\end{tabular}

\subsection{Augmented Dickey-Fuller Test}

A test used for a unit root in time series data and is an extended variant of the DickeyFuller test for a more and progressively complex course of action of time series models. We have utilized it to see the stationarity of variables of interest for this study. The outcomes represent that barely any factors are fixed at levels and some are at first difference.

\section{Table 5}

\section{Augmented Dickey-Fuller test table}

\begin{tabular}{llll}
\hline Variables & Level & 1st difference & Results \\
GDPDEF & 0.0014 & & $\mathrm{I}(0)$ \\
BD & 0.4300 & 0.000 & $\mathrm{I}(1)$ \\
OER & 0.1583 & 0.0110 & $\mathrm{I}(1)$ \\
M2 & 0.05 & - & $\mathrm{I}(0)$ \\
UNEMP & 0.5324 & 0.0000 & $\mathrm{I}(1)$ \\
GDPG & 0.026 & - & $\mathrm{I}(0)$ \\
\hline
\end{tabular}

\subsection{Estimation of the ARDL}

To experimentally examine the long run and short-run relationship and dynamic in the GDP Deflator and other informative components the model has been surveyed by ARDL bound test approach to manage co-coordination. 
Table 6

Autoregressive Distributed Lag estimated Bases on (SC)

\begin{tabular}{lllll}
\hline Variables & Co-efficient & Std error & T-statistics & Prob \\
DEF(-1) & $0.015273^{*}$ & 0.218134 & 0.070018 & 0.9449 \\
FD & $-1.599532^{* *}$ & 0.668644 & -2.392201 & 0.0272 \\
FD $(-1)$ & $0.785123^{*}$ & 0.520195 & 1.509285 & 0.1477 \\
FD $(-2)$ & $-2.532588^{* *}$ & 0.668029 & -3.791136 & 0.0012 \\
GDPG & $-0.584191^{*}$ & 0.514899 & -1.134574 & 0.2707 \\
GDPG $(-1)$ & $0.976770^{*}$ & 0.643179 & 1.518659 & 0.1453 \\
M & $-0.561219^{*}$ & 0.394136 & -1.423923 & 0.1707 \\
M(-1) & $0.654711^{*}$ & 0.572201 & 1.144197 & 0.2668 \\
M(-2) & $1.043781^{* *}$ & 0.443104 & 2.355614 & 0.0294 \\
OER & $-0.951614^{* *}$ & 0.472401 & -2.014418 & 0.0583 \\
OER(-1) & $0.724251^{* * *}$ & 0.447438 & 1.618663 & 0.1220 \\
UNEMP & $-0.687604^{*}$ & 0.690273 & -0.996134 & 0.3317 \\
UNEMP(-1) & $0.278038^{*}$ & 0.867328 & 0.320596 & 0.7520 \\
UNEMP(-2) & $-3.239194^{* * *}$ & 0.985496 & -3.286866 & 0.0039 \\
\hline & Note: $* * *$ indicates $1 \%, * *$ indicates $5 \%$ and * indicates $10 \%$ significance level
\end{tabular}

Table 7

Estimation of Bound Test Results of Bound Test

\begin{tabular}{lll}
\hline Test statistics & Value & $\mathrm{K}$ \\
F-STATISTICS & 5.824715 & 5 \\
Critical Value Bounds & & \\
Significance & I0 Bound & I1 Bound \\
$10 \%$ & 1.81 & 2.93 \\
$5 \%$ & 2.14 & 3.34 \\
$2.5 \%$ & 2.44 & 3.71 \\
$1 \%$ & 2.82 & 4.21 \\
\hline
\end{tabular}

By inspecting the consequences of a bound test in the above table, we can excuse the invalid theory of Co-integration which implies co-integration exists. We have dismissed the null hypothesis based on notable F-statistics esteem because the determined F-statistics 5.824715 is higher than both upper bound qualities 2.93 at $10 \%$ level of Significance and other upper qualities 3.34 at $5 \%$ level of significance and $2.5 \%$ level of critical estimation of upper bound is 3.71 and at $1 \%$ level of significance is 4.21 . When GDP deflator is the principal variable and all others are independent factors. Subsequently, we state that there is a long run co-combination relationship among these factors. In the wake of finding the co-integration relationship among the components now, we will move to assess the long-run coefficients under ARDL.

\subsection{Long Run and Results ARDL}

To experimentally break down since long-run and short-run relationship and dynamic collaboration among the visitor appearance and other illustrative factors, the model has been surveyed by applying the ARDL bound test approach to manage co-combination. For ARDL it is basic to choose the solicitation for slack and pick the accompanying models Akaike information criteria and Schwarz Bayesian criteria for Optimal lag. To acquire ideal lag we embrace Schwarz Bayesian data measures for ideal lag.

Auto-Regressive Distributive applied to gauge the impact of spending shortfall on inflation in Pakistan. According to the table above Supply of money, Joblessness, Official rate of exchange, and GDP growth and Fiscal deficit are independent variables. The fiscal shortfall, Supply of money, Official rate of exchange, and Unemployment has significant while GDP expansion has an insignificant impact on the long-run analysis. Some variables have a positive 
impact and some variables harm long-run analysis. In the long-term fiscal deficit, the supply of money and GDP growth has a positive impact on Inflation. As we know that when money supply increases inflation increases because people will have more cash in hand this will lead to a decrease in their purchasing power. Similarly, same is the case with a fiscal shortfall and GDP expansion as the deficit increases the inflation starts to go up with it because to cover up this deficit government needs money which they may get from external borrowing or they can print new currency which will lead towards high inflation. And now if we talk about GDP growth as we know growth occurs when people do businesses and people do businesses when they have more money in hand so when people have more money in hand it means they will have increased demand for commodities which will eventually increase the price level so there is some evidence which proves this positive relationship. While we are talking about model diagnostics, we check $\mathrm{R}^{2}$ which is respectively $70 \%$ which means that independent variables are $70 \%$ explain the dependent variable. To check the autocorrelation in the model we will see the Durbin Watson value. Which is2.379893which indicates that there is no autocorrelation.

Table 8

ARDL results with Model diagnostics

\begin{tabular}{|l|l|l|l|l|}
\hline Variable & Co-efficient & Standard error & T-statistics & Prob \\
\hline FD & $3.398910^{* *}$ & 0.966247 & 3.517641 & 0.0023 \\
\hline GDPG & $0.398668^{*}$ & 0.736499 & 0.541301 & 0.5996 \\
\hline M & $1.154912^{* *}$ & 0.272542 & 4.237550 & 0.0004 \\
\hline OER & $-0.230889^{* *}$ & 0.066141 & -3.490869 & 0.0024 \\
\hline UNEMP & 1.188467 & -3.117757 & 0.0057 \\
\hline Model Diagnostics & 0.709 \\
\hline R-Squared & \multicolumn{3}{l|}{} \\
\hline Adjusted R-Square & 0.510 \\
\hline Durbin-Watson Stat & 2.379 \\
\hline LM Test & 0.283 \\
\hline \multicolumn{4}{|l|}{} \\
\hline
\end{tabular}

Note: $* * *$ indicates $1 \%, * *$ indicates $5 \%$ and $*$ indicates $10 \%$ significance level

We apply the LM test for autocorrelation which indicates that there is no autocorrelation in the data.

\begin{tabular}{ll}
\hline Heteroskedasticity Test: Breusch-Pagan-Godfrey & \\
F-statistic & 0.564 \\
Prob $F(14,18)$ & 0.859 \\
\hline
\end{tabular}

According to the Breusch-pagan-god Frey test which indicates that there is no heteroskedasticity in the model.

\subsection{Discussion}

In the above results, the fiscal shortfall has a positive and huge impact on price expansion in Pakistan. As fiscal deficit expands the inflation also goes up. These results are the same as the study done by Catao and Terrones (2005) have. In the above results, the supply of money has a positive and significant influence on CPI in Pakistan. As the money supply increases it diminishes the estimation of cash or in other words inflation goes up. These 
iRASD Journal of Economics, 1(1), 2019

results are also the same as the study done by Grauwe and Polan (2005). In the above results GDP growth has a positive but insignificant effect on inflation in Pakistan. Some pieces of evidence support the positive relationship of GDP growth and inflation as when growth occurs inflation comes with it. In the above results, the official rate of exchange has a negative and significant effect on inflation in Pakistan. As we know that as the official rate of exchange increases inflation decreases. Our results are the same as in the study done by Lee (1992). In the above results, unemployment has a negative and significant effect on inflation in Pakistan. These results are supported by the Phillips curve which expresses that with monetary development comes inflation, which thusly should prompt more occupations and less joblessness.

\section{Table 9}

Short Run Estimation of error correlation using ARDL

\begin{tabular}{lllll}
\hline Variables & Co-efficient & Std Error & T-Stat & Prob \\
D(FD) & 1.599532 & 0.668664 & 2.392201 & 0.0272 \\
F(FD(-1)) & 2.532588 & 0.668029 & 3.791136 & 0.0012 \\
D(GDPG) & -0.584191 & 0.514899 & -1.134574 & 0.2707 \\
D(M) & -0.561219 & 0.39136 & -1.423923 & 0.1707 \\
D(M(-1)) & -1.043781 & 0.443104 & -2.355614 & 0.0294 \\
D(OER) & -0.951614 & 0.472401 & -2.014418 & 0.0583 \\
D(UNEMP) & -0.687604 & 0.690273 & -0.996134 & 0.3317 \\
D(UNEMP $(-1))$ & 3.239194 & 0.985496 & 3.286866 & 0.0039 \\
COINTEQ $(-1)$ & -0.984727 & 0.218134 & -4.514311 & 0.0002 \\
\hline
\end{tabular}

\subsubsection{Error Co-Relation Method}

The short-run dynamics coefficients from the estimation of the ARDL are like our past lag determinations the error correlation lag for the ARDL is chosen through Schwarz measures (SC). As can be found in the table the evaluated mistake coefficient is noteworthy with a negative sign. The coefficient of ECM is -0.984727 which is recommended that deviation from long term harmony is remedied by $98 \%$ over the next years.

\subsubsection{Fiscal Deficit}

In the above results, the fiscal shortfalls have a positive and prominent influence on inflation in Pakistan. As fiscal deficit increases the inflation also goes high. These results are the same as the study done by Catao and Terrones (2005) have.

\subsubsection{Money Supply}

In the above outcomes, the supply of money has a positive and noteworthy impact on inflation in Pakistan. As the money supply increases it reduces the worth of money or in other words inflation increases. These results are also the same as the study done by Grauwe and Polan (2005).

\subsubsection{GDP Growth}

In the above results GDP growth has a positive but irrelevant impact on inflation in Pakistan. There are some shreds of evidence that support the positive relationship of GDP growth and inflation as when growth occurs inflation comes with it. 


\subsubsection{Official Exchange Rate}

In the above outcomes, the official rates of exchange have a negative and significant effect on CPI in Pakistan. As we know that as the official exchange rate increases inflation decreases. Our results are the same as in the study done by Lee (1992).

\subsubsection{Unemployment}

In the above results, unemployment has a negative and huge impact on expansion in Pakistan. These results are supported by the Phillips curve which states that financial development comes inflation, which thus should prompt more occupations and less joblessness.

\section{Conclusion and Policy Recommendation}

\subsection{Key Findings}

The fiscal shortfall, Supply of money, Official rate of exchange, and Unemployment has significant while GDP expansion has an insignificant influence on the long-run examination. Some variables have a positive impact and some variables harm long-run analysis. In the long-term fiscal deficit, the supply of money and GDP growth has a positive impact on Inflation. As we know that when money supply increases inflation increases because people will have more cash in hand this will lead to a decrease in their purchasing power. Similarly same is the case with a fiscal shortfall and GDP expansion as the deficit increases the inflation starts to go up with it because to cover up this deficit government needs money which they may get from external borrowing or they can print new currency which will lead towards high inflation. And now if we talk about GDP growth as we know growth occurs when people do businesses and people do businesses when they have more money in hand so when people have more money in hand it means they will have increased demand for commodities which will eventually increase the price level so there are some pieces of evidence which proves this positive relationship. the official rate of exchange has a negative and noteworthy impact on inflation in Pakistan. As we know that as the official rate of exchange increases inflation decreases. While if we talk about joblessness it has a huge and negative impact on expansion clarified by Phillips curve which expresses that there is a negative connection among joblessness and inflation.

\subsection{Policy Recommendation}

Several steps should be taken to solve these various issues such as the government should find ways to generate revenue to cover its expenses rather than foreign financing because it will cause the general value level to go up causing a high level of inflation. The government should need to diminish its acquiring because public borrowing builds inflation high in Pakistan. We need to stable the GDP development rate to control inflation. Control fluctuation in Exchange rate to control inflation. M2 ought to likewise be observed cautiously because abundance cash gracefully causes inflation.

\subsection{Limitations of Study}

There are different restrictions of this investigation due to which some aspects could not be covered such as time constraints, the unavailability of data is also considered as another constraint because due to this missing data we could not include some additional variables. Financial constraint was also another issue. 


\subsection{Suggestions for Further Research}

I would like to further suggest researchers who will conduct study specifically in this area to invest some time in this field and try to scratch maximum data so that good estimates could find out. They should also invest some money in purchasing data and other helpful material.

\section{Conflict of Interests/Disclosures}

The authors declared no potential conflicts of interest w.r.t the research, authorship and/or publication of this article.

\section{References}

Aamir, S. (2015). The relationship and impact of money growth and budget deficit on inflation in Pakistan. VFAST Transactions on Education and Social Sciences, 5(2).

Aghevli, B. B., \& Khan, M. S. (1978). Government deficits and the inflationary process in developing countries. Staff Papers, 25(3), 383-416.

Akcay, O. C., Alper, C. E., \& Ozmucur, S. (1996). Budget deficit, money supply and inflation: Evidence from low and high frequency data for Turkey. Bogazici University Research Papers(12).

Boyd, J. H., Levine, R., \& Smith, B. D. (2001). The impact of inflation on financial sector performance. Journal of monetary Economics, 47(2), 221-248.

Catao, L. A., \& Terrones, M. E. (2005). Fiscal deficits and inflation. Journal of monetary Economics, 52(3), 529-554.

Chaudhary, M. A., Ahmad, N., \& Siddiqui, R. (1995). Money Supply, Deficit, and Inflation in Pakistan [with Comments]. The Pakistan Development Review, 34(4), 945-956.

Darrat, A. F. (2000). Are budget deficits inflationary? A reconsideration of the evidence. Applied Economics Letters, 7(10), 633-636.

Dhakal, D., Kandil, M., Sharma, S. C., \& Trescott, P. B. (1994). Determinants of the Inflation rate in the United States: A VAR Investigation. The Quarterly Review of Economics and Finance, 34(1), 95-112.

Egwaikhide, F. O., Chete, L. N., \& Falokun, G. O. (1994). Exchange rate depreciation, budget deficit and inflation: The Nigerian experience.

Fatima, G., Ahmed, A., \& Rehman, W. (2011). Fiscal deficit and economic growth: an analysis of Pakistan's economy.

Fatima, G., Ahmed, M., \& Rehman, W. (2012). Consequential effects of budget deficit on economic growth of Pakistan. International Journal of Business and Social Science, 3(7).

Grauwe, P. D., \& Polan, M. (2005). Is inflation always and everywhere a monetary phenomenon? Scandinavian Journal of Economics, 107(2), 239-259.

Habibullah, M. S., Cheah, C.-K., \& Baharom, A. (2011). Budget deficits and inflation in thirteen Asian developing countries. International Journal of Business and Social Science, 2(9).

Hondroyiannis, G., \& Papapetrou, E. (1997). Are budget deficits inflationary? A cointegration approach. Applied Economics Letters, 4(8), 493-496.

Hossain, A. (1990). The monetarist versus the neo-Keynesian views on the acceleration of inflation: Some evidence from South Asian countries (with special emphasis on Pakistan). The Pakistan Development Review, 19-31.

Iqbal, N., ud Din, M., \& Ghani, E. (2017). The Fiscal Deficit and Economic Growth in Pakistan: New Evidence.

Ishaq, T., \& Mohsin, H. M. (2015). Deficits and inflation; Are monetary and financial institutions worthy to consider or not? Borsa Istanbul Review, 15(3), 180-191.

Kakar, Z. K. (2011). Impact of fiscal variables on economic development of Pakistan. Romanian Journal of Fiscal Policy (RJFP), 2(2), 1-10. 
Lee, B. S. (1992). Causal relations among stock returns, interest rates, real activity, and inflation. The Journal of Finance, 47(4), 1591-1603.

Lozano-Espitia, L. I. (2008). Budget deficit, money growth and inflation: evidence from the Colombian case. Borradores de Economía; No. 537.

Muhammad, S. D., Zafar, S., Noman, M., \& Arfeen, N. (2016). The nexuses between budget deficit and price inflation in Pakistan: An ARDL bound testing approach. Pakistan Journal of Commerce and Social Sciences (PJCSS), 10(3), 606-614.

Mukhtar, T., \& Zakaria, M. (2010). Budget Deficit, Money Supply and Inflation: The Case of Pakistan. Economic Trends \& Economic Policy, 20(122).

Ofori, C. F., Danquah, B. A., \& Zhang, X. (2017). The Impact of Money Supply on Inflation, A Case of Ghana. Imperial Journal of Interdisciplinary Research (IIJR), 3(1), 2312-2318.

Protopapadakis, A. A., \& Siegel, J. J. (1987). Are money growth and inflation related to government deficits? Evidence from ten industrialized economies. Journal of International Money and Finance, 6(1), 31-48.

Samimi, A. J., \& Jamshidbaygi, S. (2011). Budget deficit and inflation: A sensitivity analysis to inflation and money supply in Iran. middle-east Journal of scientific research, 8(1), 257260.

Serfraz, A., \& Anwar, M. (2009). Fiscal Imbalances and Inflation: A Case Study of Pakistan. Pakistan journal of social sciences (PJSS), 29(1).

Soomro, R. H., \& Memon, A. S. Empirical Study of Relationship between Budget Deficits and Inflation: A Case Study of Pakistan.

Tiwari, A. K., Bolat, S., \& Koçbulut, Ö. (2015). Revisit the budget deficits and inflation: Evidence from time and frequency domain analyses. theoretical economics letters, 5(03), 357.

Tiwari, A. K., \& Tiwari, A. (2011). Fiscal Deficit and Inflation: An empirical analysis for India. Romanian Economic Journal, 14(42).

ur Rehman, F., Ahmed, K. A., \& Ali, S. (2008). The Impact of Budget Deficit on Inflation in Pakistan:(1970-2004). European Journal of Scientific Research, 20(3), 715-720. 